\title{
Reservoir dan Kasus Leptospirosis di Wilayah Kejadian Luar Biasa
}

\author{
Reservoir and Case of Leptospirosis in Outbreak Area
}

\author{
Tri Ramadhani, Bambang Yunianto
}

Balai Penelitian dan Pengembangan Pengendalian Penyakit Berbasis Binatang Banjarnegara

\begin{abstract}
Abstrak
Kabupaten Kulonprogo adalah salah satu daerah dengan masalah leptospirosis penyakit zoonosis yang dapat menginfeksi spesies hewan dan manusia. Studi ini bertujuan untuk mengetahui reservoir dan distribusi kasus leptospirosis pasca-kejadian luar biasa di Kabupaten Kulonprogo. Metode yang digunakan adalah inkriminasi bakteri Leptospira sp. pada tikus dan penegakan diagnosis pada manusia dengan rapid test dan MAT. Sumber data yang digunakan adalah data sekunder dan data primer dengan melakukan screening di Rumah Sakit dan Puskesmas. Penelitian observasional ini menggunakan rancangan studi cross sectional dengan metode analisis data secara distribusi frekuensi dalam bentuk gambar, grafik, dan tabel. Penelitian menemukan jumlah penderita leptospirosis di Kabupaten Kulonprogo tahun 2011 adalah 273 kasus dengan angka fatalitas 6,59\%. Kasus leptospirosis paling banyak terjadi di Kecamatan Nanggulan $(20,5 \%)$, pada laki-laki $(76,6 \%)$ dan kelompok umur $40-60$ tahun $(43,2 \%)$. Uji serologi (MAT) penderita suspek leptospirosis menemukan $41(22,5 \%)$ penderita positif mengandung bakteri Leptospira sp. Serovar yang paling banyak ditemukan adalah Harjo, Semaranga, Icterohaemorhagie, Bataviae, Patoc dengan titer $1: 40 \sim 1: 1.600$. Spesies tikus yang menjadi reservoir Leptospira sp. yang ditemukan meliputi Rattus tanezumi, Rattus tiomanicus, Mus musculus, N fluvescens, juga ditemukan insektivora jenis Suncus murinus. Trap success ditemukan sekitar $6,9 \%$ di luar rumah dan sekitar 5,5\% di dalam rumah.

Kata kunci: Kejadian luar biasa, leptospirosis, reservoir
\end{abstract}

\footnotetext{
Abstract

Kulonprogo regency is one region with leptopsirosis problem. This study aims to determine the reservoir and the case distribution of leptospirosis outbreaks in the Kulonprogo regency post. The method used is inkriminasi Leptospira sp. bacteria in mice and human with rapid test and MAT diagnosis. Leptospirosis case data taken from secondary data and primary data by conducting screening at the hospital and puskesmas. Observational re-
}

search using cross-sectional study design. Data analyzing was performed using frequency distribution with pictures, graphics and tables. The results showed leptospirosis cases in the Kulonprogo regency in 2011 as much 273 cases with CFR $6.59 \%$. The biggest number of distribution of leptospirosis cases were in District Nanggulan (20.5\%), in men (76.6\%), and $40-60$ years age group (43.2\%). Serological test (MAT) patients with suspected leptospirosis from 182 serum showed that 41 (22.5\%) patients leptospires bacteria positive. Serovar most commonly found in patients with leptospirosis is Harjo, Semaranga, Icterohaemorhagie, Bataviae, Patoc with a titer of 1: $40 \sim 1$ : 1600. Species of mice that become Leptospira sp. reservoir found were Rattus tanezumi, Tiomanicus rattus, Mus musculus, N fluvescens, insectivores Suncus murinus type was also found. Trap success by $6.9 \%$ outside home and $5.5 \%$ in house.

Keywords: Outbreak, leptospirosis, reservoir

\section{Pendahuluan}

Leptospirosis adalah penyakit infeksi akut yang dapat menyerang manusia dan hewan, serta digolongkan penyakit zoonosis. Berdasarkan penyebab, leptospirosis adalah zoonosis bakterial, sedangkan berdasarkan cara penularan, leptospirosis merupakan direct zoonosis karena tidak memerlukan vektor. Leptospirosis pada manusia ditularkan oleh hewan yang terinfeksi kuman Leptospira $s p$. dengan reservoir utama adalah roden. Kuman Leptospira $s p$. hidup di dalam ginjal penjamu reservoir dan dikeluarkan melalui urin saat berkemih. Penyakit ini terdistribusi luas di seluruh dunia dan dilaporkan pertama kali pada tahun 1886 oleh Adolf Weil dengan gejala

Alamat Korespondensi: Tri Ramadhani, Balai Litbang Pengendalian Penyakit Berbasis Binatang Banjarnegara, Jl. Selamanik No. 16 A Banjarnegara Jawa Tengah 53415, Hp.081391449575, e-mail: 3rdhani@gmail.com 
panas tinggi disertai beberapa gejala gangguan saraf serta pembesaran hati dan limfa. ${ }^{1}$ International Leptospirosis Society (ILS) menyatakan Indonesia sebagai negara dengan kasus leptospirosis cukup tinggi dan menduduki peringkat mortalitas ketiga di dunia. Hal ini didasarkan pada jumlah kasus Leptopirosis di DKI Jakarta akibat banjir besar yang terjadi tahun 2002 mencapai 113 pasien dan 20 orang di antaranya meninggal (Case Fatality Rate Leptospirosis adalah 19,4\%). ${ }^{2}$

Di Indonesia, seperti yang dilaporkan dalam risalah Partoatmodjo, leptospirosis telah ada sejak tahun 1936 dan diisolasi berbagai serovar Leptospira sp. dari hewan liar dan hewan piaraan. Di Ambarawa hewan tersebut berupa bataviae, ichterohaemorrhagiae, javanica, pyrogenes dan semaranga. ${ }^{2}$ Sekitar 170 serovar Leptospira $s p$. diidentifikasi di Indonesia dengan wilayah sebaran meliputi Jawa Tengah, Yogyakarta, Jawa Barat, Sumatera Utara, Riau, Jambi, Sumatera Selatan, Bengkulu dan Kalimantan Timur. ${ }^{2}$ Spesies Leptospira sp. interogans terdiri dari 23 serogroups dan 240 serotypes (serovars). ${ }^{3}$ Jenis yang paling sering menimbulkan penyakit berat dan fatal adalah serotype icterohemorrhagiae. Leptospira sp. dapat ditemukan pada binatang peliharaan seperti anjing, sapi, babi, kerbau, atapun binatang liar seperti tikus, musang, dan tupai. Di dalam tubuh berbagai hewan yang juga berperan sebagai penjamu reservoir, Leptospira sp. hidup di ginjal dan air kemih. ${ }^{4}$ Manusia dapat terinfeksi bakteri Leptospira sp. karena kontak dengan air atau tanah yang terkontaminasi urin atau cairan tubuh lain hewan yang terinfeksi bakteri Leptospira $s p$. dan masuk lewat kulit yang luka atau membran mukosa. 5,6

Sejak lima tahun terakhir, di Provinsi Daerah Istimewa Yogyakarta, kasus leptospirosis mengalami peningkatan. Pada tahun 2006, jumlah kasus leptospirosis dilaporkan sebanyak 16 kasus dengan 3 kasus kematian $(\mathrm{CFR}=18,75 \%)$, tahun 2007 terdapat 4 kasus dengan 1 kematian $(\mathrm{CFR}=25 \%)$, tahun 2008 terdapat $14 \mathrm{ka}-$ sus dengan 2 kematian (CFR $=14,28 \%$ ), tahun 2009 terdapat 92 kasus dengan 6 kematian $(\mathrm{CFR}=6,52 \%)$, serta tahun 2010 terdapat 186 kasus dengan 17 kematian $(\mathrm{CFR}=9,14 \%)$. Di Kabupaten Kulonprogo, jumlah kasus leptospirosis pada tahun 2010 mencapai 38 kasus dengan 4 kematian $(C F R=10,5 \%)$. Pada tahun 2011, terjadi kejadian luar biasa (KLB) dengan jumlah kasus mencapai 273 (CFR = 6,59\%) dan 18 kematian.

Semua kasus leptospirosis terjaring dan dilaporkan oleh unit pelayanan kesehatan rumah sakit sebab fasilitas di rumah sakit lebih lengkap, sehingga diagnosis dapat ditegakkan. Meskipun secara klinis telah terdiagnosis di puskesmas, pengetahuan petugas dan sarana yang kurang untuk penegakan diagnosis, sehingga penderita tidak terdiagnosis. Selain itu, terdapat diferensial diagnosis leptospirosis yang sama dengan penyakit yang lain. Tingginya angka kematian yang tercatat di rumah sakit
$(\mathrm{CFR}=12,8 \%)$ menunjukkan kasus leptospirosis yang terdiagnosis dengan gejala sedang atau berat. Sebagian besar pasien kasus leptospirosis telah mengalami kerusakan fungsi ginjal, sehingga memerlukan hemodialisis. Kondisi tersebut berdampak signifikan bagi kesehatan masyarakat di wilayah Kabupaten Kulonprogo, mengingat sebagian besar masyarakat belum mengetahui gejala klinis, penyebab, faktor risiko, dan cara penanggulangannya.

Saat ini, upaya pemerintah daerah terbatas pada pencarian dan pengobatan penderita, belum secara komprehensif melibatkan semua faktor yang terlibat. Salah satu upaya tersebut adalah dilaksanakan penilaian cepat ( $\mathrm{ra}$ pid assessment) leptospirosis pascakejadian luar biasa untuk mengetahui besaran masalah kesehatan yang dihadapi dan upaya pengendalian untuk memutuskan rantai penularan. Tujuan dari penelitian ini adalah mendeskripksikan reservoir dan karakteristik penderita leptospirosis.

\section{Metode}

Penelitian observasional ini menggunakan rancangan studi cross sectional yang dilakukan di wilayah Kabupaten Kulonprogo yang merupakan salah satu daerah yang mengalami kejadian luar biasa leptospirosis di Provinsi Daerah Istimewa Yogyakarta. Survei dilakukan bulan Maret hingga Oktober 2011, dengan populasi seluruh pasien yang datang ke puskesmas, rumah sakit, dan unit pelayanan kesehatan lain. Sampel adalah pasien yang datang ke puskesmas dengan menunjukan gejala klinis leptospirosis, utamanya demam dengan suhu badan $>37^{\circ} \mathrm{C}$ atau demam disertai sakit kepala, nyeri otot, konjungtivitis, dan ruam. Diagnosis leptospirosis dilakukan melalui pengambilan sampel darah vena seki$\operatorname{tar} 3 \mathrm{ml}$ oleh dokter atau paramedis terlatih, kemudian diambil serum untuk diuji secara cepat dengan Leptotek Lateral Flow yang dilanjutkan dengan uji Microscopic Aglutination Test (MAT).

Data karakteristik responden meliputi umur, jenis kelamin, pendidikan, dan pekerjaan dikumpulkan melalui wawancara dengan kuesioner. Data lingkungan biotik mencakup keberadaan tikus yang meliputi spesies, habitat, trap success, kandungan, dan strain bakteri Leptospira sp. Data populasi tikus didapatkan dengan cara penangkapan tikus secara periodik menggunakan "life trap" dengan umpan kelapa bakar dan ikan asin. Dua unit perangkap tikus diletakkan di dalam rumah dan dua unit di luar rumah/kebun selama 3 malam dan dilakukan identifikasi setiap pagi hari. Jumlah perangkap adalah 300 buah yang dipasang mulai pukul $16.00 \mathrm{WIB}$ dan diambil pada pukul 06.00 - 08.00 setiap hari berikutnya. Tikus yang tertangkap diidentifikasi untuk menentukan spesies serta pengambilan darah atau serum untuk pemeriksaan bakteri Leptospira sp. Identifikasi 
tikus menggunakan kunci identifikasi dari Modul Pelatihan Rodentologi Balai Besar Penelitian dan Pengembangan Vektor dan Resevoir Penyakit (B2P2VRP) Salatiga. ${ }^{7}$ Pemeriksaan bakteri Leptospira $s p$ pada manusia dan tikus dilakukan di Laboratorium Mikrobiologi Universitas Diponegoro Semarang dan Balai Besar Penelitian Veteriner (BBalitvet) Bogor. Analisis data dilakukan secara univariat dan disajikan dalam bentuk tabel dan gambar.

\section{Hasil}

Kabupaten Kulonprogo merupakan wilayah bagian Provinsi DIY yang terletak di wilayah paling barat, di sebelah barat dan utara berbatasan dengan Provinsi Jawa Tengah dan sebelah selatan berbatasan dengan Samudera Indonesia, secara geografis terletak antara $7^{\circ} 38^{\prime} 42$ " -70 $59^{\prime} 3$ " lintang selatan dan $110^{\circ} 1^{\prime} 37^{\prime \prime}-110^{\circ} 16^{\prime} 26^{\prime \prime}$ bujur timur. Secara umum kondisi wilayah Kabupaten Kulonprogo adalah daerah datar, meskipun dikelilingi pegunungan yang sebagian besar terletak pada wilayah utara. Luas wilayahnya $17,58 \%$ berada pada ketinggian $<7 \mathrm{~m}$ di atas permukaan laut, $15,20 \%$ pada ketinggian $8-25 \mathrm{~m}$ di atas permukaan laut, $22,85 \%$ berada pada ketinggian $26-100 \mathrm{~m}$ di atas permukaan laut, 33,00\% berada pada ketinggian $101-500 \mathrm{~m}$ diatas permukaan laut dan $11,37 \%$ berada pada ketinggian $>500 \mathrm{~m}$ diatas permukaan laut. Kabupaten Kulonprogo berada sekitar $25 \mathrm{~km}$ arah barat Kota Yogyakarta dengan aksesibilitas yang baik dan mudah dijangkau, terhubung dengan kota-kota di Jawa bagian selatan oleh jalur transportasi regional Jawa bagian selatan melalui jalan raya dan kereta api.

\section{Epidemiologi Kasus Leptospirosis}

Kejadian leptospirosis di Kabupaten Kulonprogo mulai terdiagnosis pada tahun 2007 sebanyak 2 kasus. Selanjutnya, setiap tahun dilaporkan terdapat kasus, tetapi pada tahun 2010, mulai terjadi kenaikan yang signifikan sebanyak 55 kasus dengan 8 kematian (CFR = $14,55 \%)$. Kondisi ini terus berlangsung hingga akhir tahun 2011 sehingga terjadi KLB leptospirosis dengan kasus 273 dan kematian 18 orang (CFR $=6,59 \%$ ). Meskipun terjadi penurunan angka kematian, jumlah kasus leptospirosis memperlihatkan tren yang meningkat. Hal ini seiring dengan peningkatan sosialisasi leptospirosis, sehingga deteksi dini dapat dilakukan sedini mungkin. Hasil kejadian leptospirosis di Kabupaten Kulonprogo selama 5 tahun terakhir secara rinci terlihat pada Gambar 1.

Berdasarkan kecamatan dan wilayah puskesmas di seluruh Kabupaten Kulonprogo, kejadian leptospirosis lebih banyak ditemukan di 5 kecamatan, meliputi Kecamatan Nanggulan (20,5\%), Girimulyo (14,7\%), Kokap (14,3\%), Samigaluh (12,1\%), dan Kalibawang

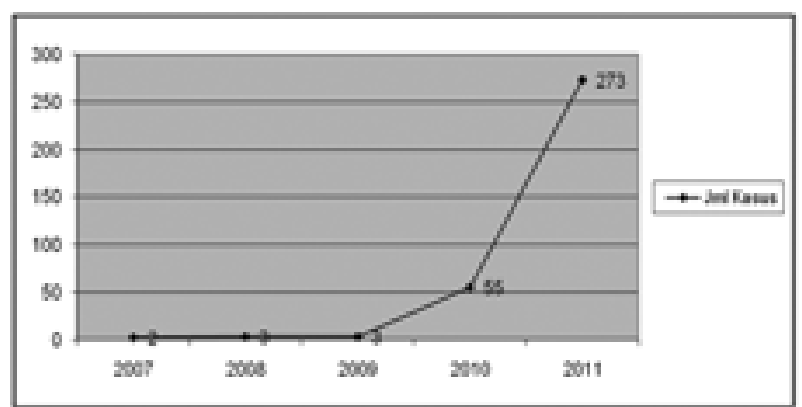

Gambar 1. Grafik Kasus Leptospirosis Setiap Tahun di Kabupaten Kulonprogo

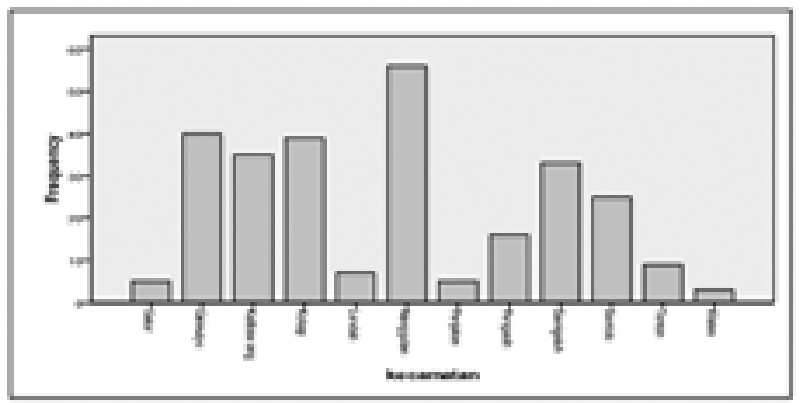

Gambar 2. Distribusi Kasus Leptospirosis per Kecamatan di Kabupaten Kulonprogo Tahun 2011

$(12,8 \%)$, sisanya tersebar di kecamatan lainnnya. Sebagian besar wilayah dengan kejadian leptospirosis berada di daerah pegunungan, sedangkan di dataran rendah hanya terjadi di Kecamatan Nanggulan (Gambar 2).

Berdasarkan waktu, pada tahun 2011, kejadian leptospirosis mulai meningkat pada bulan Februari dan mencapai puncak pada bulan Maret, setelah itu menurun terus sampai bulan Juli, dan stabil sampai akhir tahun (Gambar 3). Proporsi kejadian dan kematian leptospirosis pada laki-laki $(76,1 \%$ dan $83,3 \%$ ) lebih banyak daripada perempuan $(23,9 \%$ dan $16,7 \%)$. Kejadian leptospirosis lebih banyak menyerang pada kelompok usia dewasa (41 - 60 tahun) sebanyak 43,2\% demikian juga dengan angka kematian (7,6\%) (Tabel 1).

Hal ini berkaitan dengan risiko pekerjaan pada kelompok usia tersebut yang lebih banyak terpapar lingkungan dan secara alami daya tahan tubuhnya sudah mulai menurun. Pada kelompok anak-anak kematian karena leptospirosis tidak ditemukan, hal ini mengindikasikan bahwa kasus leptospirosis yang menyerang anak-anak segera dapat terdiagnosis, sehingga upaya pengobatan segera ditangani.

Hasil identifikasi strain Leptospira sp. dengan metode Medial Axis Transform menunjukkan bahwa strain yang paling banyak ditemukan pada sampel yang positif Leptospira sp. adalah Harjo, Semaranga, Icterohae- 


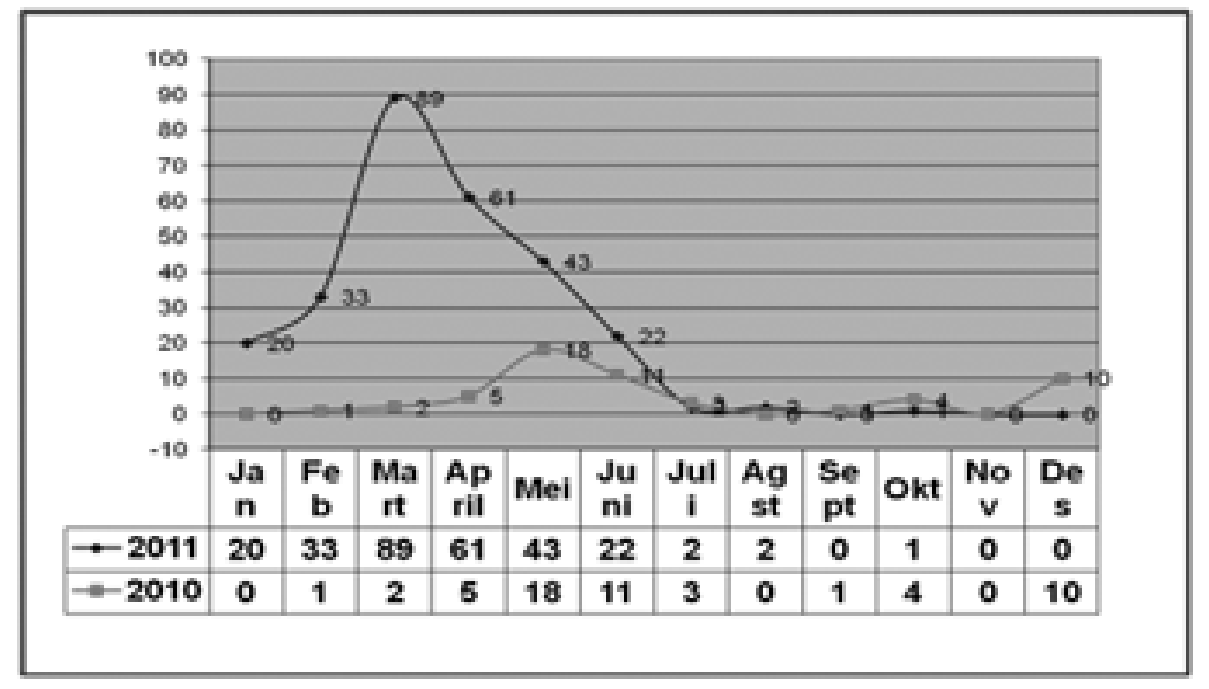

Gambar 3. Grafik Distribusi Kasus Leptospirosis per Bulan di Kabupaten Kulonprogo Tahun 2011

Tabel 1. Angka Kejadian Leptospirosis dan CFR Menurut Jenis Kelamin di Kabupaten Kulonprogo Tahun 2011

\begin{tabular}{llllll}
\hline Variabel & Kategori & Jumlah Kasus & $\%$ & Jumlah Kematian & $\%$ \\
\hline Jenis kelamin & Laki - laki & 211 & 76,1 & 15 & 83,3 \\
& Perempuan & 62 & 23,9 & 3 & 16,7 \\
Kelompok umur & $0-9$ tahun & 0 & 0 & 0 & 0 \\
& $10-20$ tahun & 11 & 3 & 0 & 0 \\
& $21-40$ tahun & 88 & 43,2 & 5 & 7,7 \\
& 41-60 tahun & 118 & 20,5 & 4 & 7,1 \\
\hline
\end{tabular}

morhagie, Bataviae, Patoc (Gambar 4).

\section{Lingkungan Biotik}

Keberadaan reservoir khususnya tikus sangat penting diketahui dalam upaya pengendalian dan pemutusan rantai penularan. Selama ini, tikus dikenal sebagai binatang yang potensial dalam penularan leptospirosis. Hasil penangkapan selama 5 kali kegiatan penangkapan diperoleh 4 spesies yaitu Rattus tanezumi, Rattus tiomanicus, Mus musculus, $N$ fluvescens. Selain itu, tidak ditemukan bakteri Leptospira sp. pada serum tikus dan tidak ditemukan insektivora jenis Suncus murinus (Tabel 2).

\section{Pembahasan}

Apabila dibandingkan dengan tahun 2010, puncak kasus terjadi pada bulan Mei dan persamaannya adalah hanya terjadi satu puncak kasus. Hal ini menunjukkan kegiatan yang cepat dalam penemuan dan diagnosis leptopsirosis terutama di puskesmas dan rumah sakit, karena disertai peningkatan sarana dan prasarana alat diagnosis cepat. Kondisi ini sedikit banyak akan mengurangi penularan di wilayah sekitar, dan penderita leptospirosis mendapatkan pengobatan yang tepat berdasarkan hasil laboratorium, mengingat gejala leptospirosis memiliki banyak kesamaan dengan penyakit lain, seperti DBD, tifus, dan hepatitis.

Proporsi kasus yang tinggi pada laki-laki kemungkinan berhubungan dengan pekerjaan, sebagian besar penderita leptopsirosis bekerja sebagai petani yang lebih banyak dikerjakan oleh laki-laki, sementara perempuan hanya membantu sewaktu-waktu. Penderita leptospirosis laki-laki berisiko menderita leptospirosis 9,6 kali lebih besar daripada perempuan. Hal tersebut kemungkinan karena laki-laki lebih sering terpapar dengan lingkungan yang terkontaminasi bakteri Leptospira sp. Sebagian besar aktivitas kelompok laki-laki dewasa lebih banyak kontak dengan air di sungai, di sawah, dan di tempat kerja yang berhubungan dengan air yang terkontaminasi bakteri Leptospira sp. ${ }^{8}$ Perbedaan insidensi berdasarkan gender tersebut terkait dengan pekerjaan (work task) dan personal hygiene yang menyebabkan perbedaan peluang untuk terpapar oleh bakteri Leptospira sp. yang infektif. ${ }^{9}$ Mekanisme bakteri Leptospira sp. masuk ke dalam tubuh inang dapat terjadi melalui penetrasi lewat kulit atau permukaan tubuh yang terabrasi, inhalasi dari aerosol seperti percikan urin yang terkontaminasi, atau dengan 


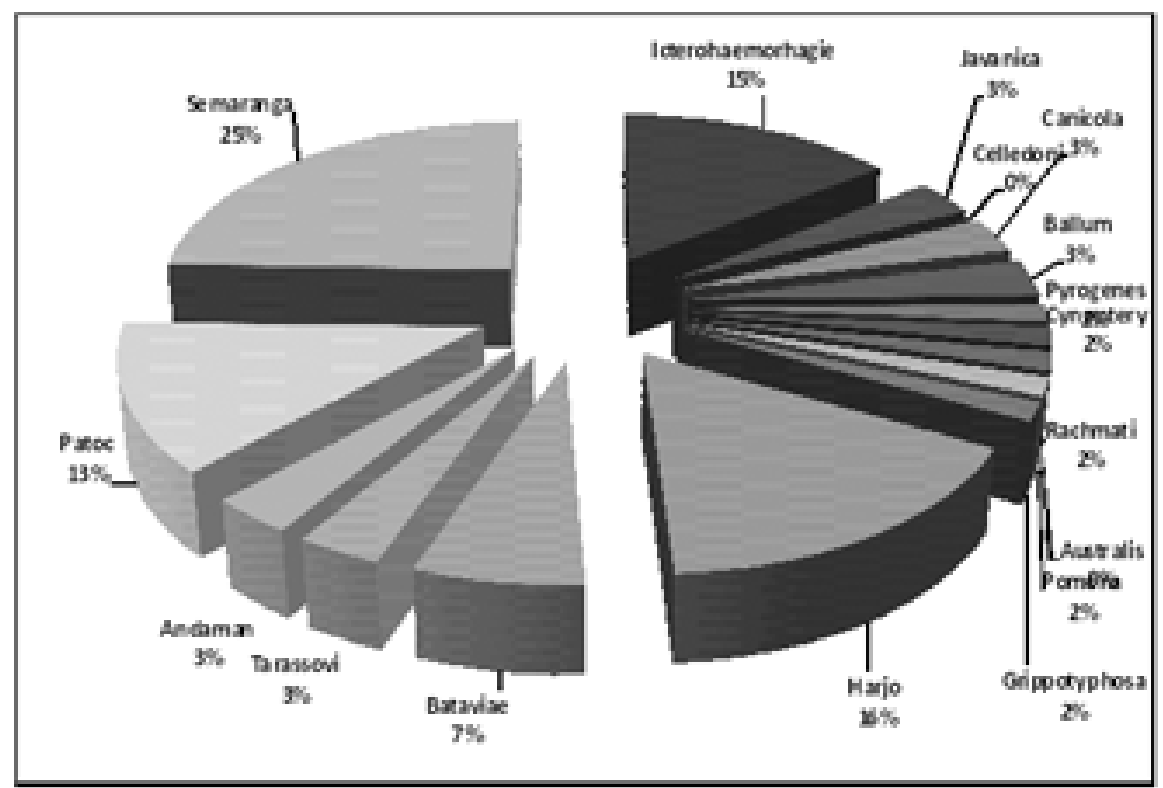

Gambar 4. Serovar Bakteri Leptospira sp. pada Serum Penderita Leptospirosis $(\mathbf{n}=\mathbf{4 1})$

Tabel 2. Spesies dan Jumlah Mamalia Kecil yang Tertangkap di Lokasi Penelitian

\begin{tabular}{|c|c|c|c|c|c|c|c|}
\hline \multirow{2}{*}{ Spesies } & \multicolumn{3}{|c|}{ Jumlah tertangkap } & \multirow{2}{*}{ Jantan } & \multirow{2}{*}{ Betina } & \multirow{2}{*}{ Jumlah } & \multirow{2}{*}{ Proporsi $(\%)$} \\
\hline & $\mathbf{L}$ & D & TL & & & & \\
\hline Rattus tanezumi & 68 & 54 & 2 & 44 & 80 & 124 & 72,36 \\
\hline Rattus tiomanicus & 8 & 0 & 0 & 4 & 4 & 16 & 4,70 \\
\hline Mus musculus & 5 & 6 & 0 & 5 & 6 & 22 & 6,48 \\
\hline N.fluvescens & 1 & 0 & 0 & 0 & 1 & 2 & 0,59 \\
\hline Suncus murinus & 15 & 17 & 0 & 2 & 20 & 54 & 15,89 \\
\hline Total & 97 & 77 & 2 & 69 & 107 & 176 & 6,59 \\
\hline Trap success & 6,9 & 5,5 & & & & & 6,3 \\
\hline
\end{tabular}

Keterangan :

L : luar rumah

D : dalam rumah

TL : tanpa label

mengonsumsi air atau susu yang terkontaminasi. ${ }^{10}$

Strain bakteri Leptospira sp. yang ditemukan selama penelitian memiliki serogroup dan serovar masing-masing. L.bataviae dan L.icterohaemorhagiae tersebut diketahui merupakan serogroup dari kelompok Leptospira interrogans yang virulen bagi manusia. Bakteri L.icterohemorrhagiae merupakan bakteri Leptospira sp. yang biasa ditemukan pada reservoir tikus dan jarang ditemukan pada binatang lain. Selain itu, bakteri tersebut infektif pada manusia. Spesies tikus yang tertangkap sebagian besar merupakan tikus yang mempunyai habitat di permukiman dan sudah beradaptasi dengan baik pada aktivitas kehidupan manusia serta menggantungkan hidupnya (pakan dan tempat tinggal) pada kehidupan manusia yang disebut sebagai commensal rodent. Tikus yang menghuni selokan (got) baik selokan kecil yang berada di sekitar permukiman, maupun selokan besar yang berada di bawah tanah di daerah perkotaan hampir tidak ditemukan, mengingat lokasi survei termasuk daerah pedesaan yang jarang terdapat saluran limbah. Jika jenis ini tidak ada di suatu wilayah maka digantikan oleh tikus rumah, sedangkan mencit rumah (Mus musculus) sangat jarang atau tidak pernah menghuni habitat selokan. ${ }^{11}$

Tikus rumah $R$. tanezumi merupakan jenis tikus yang paling banyak tertangkap di dalam rumah dan merupakan subspesies dari Rattus rattus yang umum ditemukan di rumah penduduk di Pulau Jawa. ${ }^{12}$ Akan tetapi, menurut Suyanto, 13 tikus rumah $R$. tanezumi merupakan sinonim dari Mus diardii, habitatnya di rumah, tersebar luas di Indonesia, Malaysia, dan Thailand. Tikus rumah $R$. tanezumi dikenal sebagai tikus komensal (commensal rodent atau synanthropic), karena seluruh akti- 
vitas hidupnya, seperti mencari makan, berlindung, bersarang, dan berkembang biak dilakukan di dalam rumah. Tikus ini berperan penting dalam penularan beberapa penyakit seperti pes, leptospirosis, dan penyakit cacing nematoda. Adanya tikus yang tertangkap di dalam rumah mengindikasikan lingkungan rumah yang tidak sehat. Hasil penelitian Sarkar, ${ }^{14}$ menyebutkan bahwa melihat tikus di dalam rumah berisiko 4,5 kali lebih besar untuk terjadi leptospirosis. Infeksi bakteri Leptosipra $s p$. terjadi karena kondisi lingkungan perumahan yang banyak dijumpai tikus, sehingga bila terjadi kontaminasi oleh urin tikus yang mengandung bakteri dapat dengan mudah terjangkit penyakit leptospirosis. Bakteri Leptosipra sp. banyak menyerang tikus besar seperti tikus wirok Rattus norvegicus dan tikus rumah (Rattus diardii).

Tikus betina lebih mudah ditangkap daripada tikus jantan, sebab peran tikus betina di dalam kelompok adalah mencari makan bagi anak-anaknya, sehingga memiliki mobilitas lebih tinggi daripada tikus jantan. ${ }^{11}$ Di daerah penelitian, keberhasilan penangkapan di luar rumah lebih tinggi daripada di luar rumah. Angka keberhasilan penangkapan tikus tersebut memperlihatkan bahwa kepadatan tikus di luar rumah lebih tinggi daripada di dalam rumah. Keberhasilan penangkapan ini dapat menggambarkan kepadatan populasi tikus relatif di suatu tempat atau lingkungan. Banyak tikus rumah $R$. tanezumi di dalam rumah beresiko terpapar leptospirosis meskipun di lokasi penelitian belum ditemukan bakteri Leptosipra sp. pada tikus.

Lingkungan kotor dan tertutup rerumputan atau semak belukar merupakan tempat yang disukai tikus. ${ }^{11}$ Pada kondisi yang tidak menguntungkan, seperti kekeringan, umbi akar gulma merupakan sumber pakan tikus. Selain sebagai sumber pakan, vegetasi dapat digunakan sebagai tempat untuk persembunyiaan tikus. Hasil penelitian Aplin dkk, ${ }^{12}$ menunjukkan bahwa penularan leptospirosis dapat melalui tumbuhan yang terkena urin tikus infektif bakteri Leptospira sp. yang tersentuh kulit manusia. Kondisi tersebut sangat memungkinkan penularan di lokasi penelitian sebab sebagian besar petani selain bekerja di sawah juga melakukan aktivitas mencari rumput di ladang, sehingga sangat berpotensi bersentuhan dengan vegetasi yang ada. Leptospirosis merupakan masalah kesehatan penting yang berbahaya bagi pekerja penanam padi di sawah.

Curah hujan yang tinggi akan meningkatkan paparan bakteri Leptosipra $s p$. pada manusia lewat air dan tanah yang terkontaminasi. Leptospirosis di Kabupaten Kulonprogo cenderung lebih tinggi terjadi pada saat musim hujan. Indeks curah hujan merupakan salah satu faktor risiko lingkungan abiotik dalam kejadian leptospirosis. Kejadian leptospirosis di negara tropis sering terjadi pada saat curah hujan tinggi. Indeks curah hujan yang tinggi akan meningkatkan paparan bakteri Leptospira sp. pada manusia lewat air dan tanah yang terkontaminasi. Hal ini tidak sejalan dengan penelitian lain yang menyimpulkan bahwa kejadian leptospirosis berhubungan dengan indeks curah hujan, kemungkinan faktor risiko lingkungan abiotik lain yang lebih berhubungan dengan kejadian leptospirosis.

Leptosipra sp. merupakan bakteri obligat aerob, sehingga keberadaan oksigen merupakan hal yang penting untuk kelangsungan hidupnya. Leptospira sp. peka terhadap asam dan dapat bertahan hidup di dalam air bersifat basa sampai 6 bulan dan dapat hidup di dalam air tawar selama kurang lebih satu bulan, tetapi di dalam air laut, air selokan, dan air kemih yang tidak diencerkan akan cepat mati.

\section{Kesimpulan}

Jumlah penderita leptospirosis di Kabupaten Kulonprogo tahun 2011 sebanyak 273 dengan CFR sebesar 6,59\%. Kasus leptospirosis terdistribusi di 12 wilayah Kecamatan dan terbanyak di Kecamatan Nanggulan. Kasus leptospirosis lebih banyak pada lakilaki dan golongan umur 41 - 60 tahun. Strain bakteri Leptosipra sp. yang dominan ditemukan pada serum penderita adalah Harjo, Semaranga, Icterohaemorhagie, Bataviae, Patoc dengan titer $1: 40 \sim 1: 1600$. Spesies tikus yang ditemukan Rattus tanezumi, Rattus tiomanicus, Mus musculus, $N$ fluvescens, dan insektivora jenis Suncus murinus, tingkat keberhasilan penangkapan atau trap success sebesar 6,9\% di luar rumah dan 5,5\% di dalam rumah

\section{Saran}

Perlu dilakukan pemeriksaan bakteri Leptosipra $s p$. pada hewan domestik dengan melibatkan dinas peternakan dan pertanian setempat. Sosialisasi leptospirosis khususnya tentang pengertian, gejala klinis, upaya pengobatan, diagnosis melalui media yang sudah ada dan berjalan di masyarakat meliputi karang taruna, pembinaan kesejahteraan keluarga, dasa wisma, pertemuan rukun tetangga, dan pengajian.

\section{Ucapan Terima Kasih}

Terima kasih kepada Kepala Dinas Kesehatan Kabupaten Kulonprogo beserta jajarannya yang telah membantu terlaksananya penelitian ini.

\section{Daftar Pustaka}

1. Widarso HS, Wilfried P. Kebijaksanaan Departemen Kesehatan dalam penanggulangan leptospirosis di Indonesia. Kumpulan makalah simposium Leptospirosis. Semarang: Universitas Diponegoro; 2002.

2. Fahmi U. Leptospirosis, mematikan dan sulit dideteksi. 2005 [cited 2011 Mei 19]. Available from: http://www.harian umum pelita.htm

3. Sanford JP. Leptospirosis, harrison's principles of internal medicine. 
13th ed. New York: McGraw Hill; 1994.

4. Hanggara R. Ulah leptospirosis. 2nd ed. Tahun I. Halo Internis; 2004.

5. Ashford DA, Kaiser RM, Spiegel RA, Perkins BA, Weyant RS, Bragg SL, et al. Asymptomatic infection and risk factors for Leptospirosis in Nicaragua. American Journal Tropical Medicine and Hygiene. 2000; 63(5-6): 249-54.

6. Anonymous. Leptospirosis, Harrison's manual of medicine International edition. New York: Mc Graw-Hill; 200. p. 463-4.

7. Ristiyanto. Modul pelatihan teknis tingkat dasar survei reservoar penyakit bidang minat Rodensia. Salatiga: Balai Besar Penelitian dan Pengembangan Vektor dan Resevoir Penyakit; 2007

8. Assimina Z, Fotoula B. Leptospirosis: epidemiology and preventive measures. Health Science Journal. 2008; 2 (2): 75-82.

9. Thronley JN, Baker MG, Weinstein P, Maas EW. Changing epidemiology of human Leptospirosis in New Zealand. Epidemiology Infect
Journal. 2002; 128 (1): 29-36.

10. Levett. Leptospirosis. Clinical Microbiology Reviews. 2001: 14; 296326.

11. Priyambodo S. Pengendalian hama tikus terpadu. Jakarta: PT Penebar Swadaya; 1995.

12. Aplin KP, Brown J, Jacob CJ, Krebs, Singleton GR. Field methods for rodent studies in Asia and the Indo-Pacific. Australian Centre for International Agricultural Research. Canberra: Australia; 2003.

13. Suyanto A. Mammals of Gunung Halimun National Park, West Java. Lembaga Ilmu Pengetahuan Indonesia. Bogor: Pusat Penelitian Biologi; 2004.

14. Sarkar U, Nascimento SF, Barbosa R, Martins R, Nuevo H, Kalofonos I, et al. Population-based case-control invertigation of risk factors for leptospirosis during an urban epidemic. American Journal Tropical Medicine and Hygiene. 2002; 66 (5): 605-10. 